\title{
Disturbances to the Supply Chains of High-Value Manufacturing Firms: Comparison of the Perceptions of Product Managers and Supply Chain Managers
} DOI:

10.1080/00207543.2020.1756503

\section{Document Version}

Accepted author manuscript

Link to publication record in Manchester Research Explorer

Citation for published version (APA):

Huq, F., Pawar, K., \& Subramanian, N. (2020). Disturbances to the Supply Chains of High-Value Manufacturing Firms: Comparison of the Perceptions of Product Managers and Supply Chain Managers. International Journal of Production Research. https://doi.org/10.1080/00207543.2020.1756503

Published in:

International Journal of Production Research

\section{Citing this paper}

Please note that where the full-text provided on Manchester Research Explorer is the Author Accepted Manuscript or Proof version this may differ from the final Published version. If citing, it is advised that you check and use the publisher's definitive version.

\section{General rights}

Copyright and moral rights for the publications made accessible in the Research Explorer are retained by the authors and/or other copyright owners and it is a condition of accessing publications that users recognise and abide by the legal requirements associated with these rights.

\section{Takedown policy}

If you believe that this document breaches copyright please refer to the University of Manchester's Takedown Procedures [http://man.ac.uk/04Y6Bo] or contact uml.scholarlycommunications@manchester.ac.uk providing relevant details, so we can investigate your claim.

\section{OPEN ACCESS}




\section{Disturbances to the supply chains of high- value manufacturing firms: comparison of the perceptions of product managers and supply chain managers}

\section{Fahian Huq, Kulwant S. Pawar \& Nachiappan Subramanian}

To cite this article: Fahian Huq, Kulwant S. Pawar \& Nachiappan Subramanian (2020):

Disturbances to the supply chains of high-value manufacturing firms: comparison of the perceptions of product managers and supply chain managers, International Journal of Production Research, DOI: $\underline{10.1080 / 00207543.2020 .1756503}$

To link to this article: https://doi.org/10.1080/00207543.2020.1756503

\section{Published online: 04 May 2020.}

Submit your article to this journal ¿

View related articles $\asymp$

View Crossmark data $\nearrow$ 


\title{
Disturbances to the supply chains of high-value manufacturing firms: comparison of the perceptions of product managers and supply chain managers
}

\author{
Fahian Huq (D) ${ }^{a *}$, Kulwant S. Pawar ${ }^{\mathrm{b}}$ and Nachiappan Subramanian (D) ${ }^{\mathrm{c}}$ \\ ${ }^{a}$ Management Sciences and Marketing, Manchester Business School, Manchester, UK; ${ }^{b}$ Nottingham University Business School, The \\ University of Nottingham, Nottingham, UK, ${ }^{c}$ School of Business, Management and Economics, University of Sussex, Brighton, UK
}

(Received 27 July 2018; accepted 9 April 2020)

\begin{abstract}
We draw on the literature to categorise the supply chain disturbances (risks and uncertainties) that affect high-value manufacturing (HVM) firms when adopting the following two sourcing strategies: (a) insourcing/nearshore outsourcing, and (b) outsourcing/offshoring. We build a hierarchy structure of disturbances, which was tested in a case study of a European HVM operating in the aerospace industry. A novelty of this study is the quantitative prioritisation and comparison, using the analytic hierarchy process (AHP) method, of the disturbances reported by two groups of managers: three product managers (internally facing) and four supply chain managers (externally facing). Our findings show that managers' perceptions of firmrelated, network-related and location-related disturbances can be prejudiced by their functional boundaries. We show that both product and supply chain managers prefer the insource/nearshore outsource strategy, as they feel that the disturbances while outsourcing/offshoring are significantly greater and offset the benefits of low-cost production - a counterintuitive finding. Through in-depth interviews with both groups of managers, we found the mitigation strategies are reshoring, full consideration to the total cost of acquisition (including hidden costs of distant operations) and building clusters in emerging markets to support the firm's regional hub by partnering with its existing suppliers from developed countries.
\end{abstract}

Keywords: High-Value manufacturing; disturbance factors; insourcing; outsourcing; offshoring; Strategic sourcing

\section{Introduction}

Decisions on where to locate geographically have in the past primarily been based on quantitative cost measures, without due consideration being given to other important factors, such as disturbances internal and external to the supply chain (Tate et al. 2009; Huq, Pawar, and Rogers 2016). The trend towards outsourcing and, in particular, offshore manufacturing has increased firms' vulnerability to a range of supply chain disturbances, such as hurricanes, earthquakes and political instability, as well as economic factors, such as wage inflation in lower-cost countries (Christopher and Holweg 2011; Wagner and Neshat 2012). Also, in the West, political pressures have recently arisen to bring jobs back from overseas, termed 'reshoring' (Tate 2014). This is leading multi-national companies (MNCs) to focus on coordination of the supply network and re-evaluate their supply chain sourcing strategies. Managers are weighing the relative costs and benefits of remote outsourcing/offshoring (where parts of the supply chain are transferred outside the parent firm's national borders and the site is comparatively remote) and of insourcing/near-shore outsourcing (where sourcing/manufacturing activities take place in or near the country of origin).

High-value manufacturing (HVM) firms are usually MNCs with some distinct characteristics. As Martinez et al. (2008, 5) explain: 'HVM firms do not compete primarily on cost. Instead, they deliver value for one or more of their stakeholder groups by contracting for capability, delivering product/service innovation, establishing process excellence, achieving high brand recognition and/or contributing to a sustainable society.' HVM firms generate not only sustainable profits but also higher value for their stakeholders by, for example, establishing new markets, creating innovative technologies and offering a large number of employment opportunities (Wang and Zhang 2014). A report by EngineeringUK (2017) noted that the engineering sector in the United Kingdom (UK) contributes $26 \%$ of gross domestic product (GDP), viewed in terms of gross value added. This is greater than the collective contributions of the retail, wholesale, financial and insurance sectors.

Typically, the features that distinguish the supply chain of HVM firms from those of non-HVM firms are (1) the difficulty in switching suppliers, as they rely on specialist suppliers with unique technical expertise and innovation capabilities, (2) supplier development efforts are high, as products need to be developed in close collaboration with suppliers, (3) materials

\footnotetext{
*Corresponding author. Email: fahian.huq@manchester.ac.uk
} 
and scientific engineering capabilities are rare (e.g. few suppliers have the machining capability to process titanium composite material), and (4) strict supplier selection and evaluation criteria are required, mainly due to the risks of infringement of regulatory and intellectual property rights, as demonstrated by the recent arrest of a former Rolls-Royce engineer suspected of divulging details about the UK's new F-35 stealth fighter jet to China (Telegraph 2018).

Driven by globalisation, rapidly changing markets and emerging technologies, HVM supply chains have become increasingly complex (Zhang and Gregory 2011), and sourcing, manufacturing and distribution may occur at different locations. This provides a good opportunity to study how disturbances to the supply chain, i.e. risks and uncertainties (Huq, Pawar, and Rogers 2016), affect sourcing decisions.

Aerospace is a high-tech manufacturing industry that has recently been hit by supply chain disturbances. For instance, in November 2010, internal quality issues (involving a faulty manufacturing process) led to serious failure of a Rolls-Royce Trent 900 engine at 2100 metres over Indonesia on a Qantas flight from Singapore to Sydney. According to the report by the Australian Transport Safety Bureau (ATSB), Rolls-Royce knew at least three years before the accident that components manufactured in its Hucknall plant in Nottinghamshire failed to conform to design standards. In fact, in 2009 the potential risk of these defective parts was raised by one of its engineers but Rolls-Royce did not carry out a proper investigation (Guardian 2013). Rolls-Royce lost US $\$ 1$ billion in market value the day after this accident.

Supply chain disturbances can also be due to external factors. An example of a network-level disturbance is the industry-wide shortage of aerospace fasteners (comprising approximately 3\% of an airframe's value), which halted Boeing's assembly line in 2007, causing billions of dollars of overspend due to delays (International Business Times 2014). More recently, due to the uncertainty regarding Brexit, Airbus, which directly employs 14,000 people in Britain and whose supply chain supports 110,000 jobs, announced in 2018 that it will refrain from extending its UK supplier base (Guardian 2018).

The above-mentioned cases demonstrate how important it is for firms producing HVM products to understand that disturbances can occur at all levels within the supply chain, and to identify the sources of these disturbances. Undoubtedly, managing the supply chain becomes a greater challenge when partners are operating in geographically distant emerging markets, where institutions and infrastructures are less developed (Huq and Stevenson 2018). Despite this, in the UK HVM sector, outsourcing/offshoring to distant low-cost locations is still the dominant strategy. In a survey of 300 companies by the Engineering Employers Federation (2014), 20\% of respondents reported that at least 50\% of their suppliers were outside the UK. Yet there also seemed to be an interesting shift in their sourcing decisions. The report found that in the previous three years, around $17 \%$ of respondents had reshored production in-house and the same proportion had switched to nearshore outsourcing (i.e. using a UK supplier). Moreover, an additional $6 \%$ of respondents were planning to reshore in the next three years - either in-house (i.e. insource) or to a UK/European supplier (i.e. near-shore outsource).

When supply chain managers take strategic global sourcing decisions without considering possible disturbance factors, firms may have to resort to major reconfiguration of their supply chains. The role of managers and decision makers considering supply chain disturbances has been emphasised (Dong and Cooper 2016); however, the differences in the perception of supply chain disturbances on the part of internally and externally facing managers has not received full attention in the research literature. Moreover, sourcing decisions in which the influence of disturbance factors and proactive initiatives are fully considered will enable managers to develop better mitigation strategies (Samvedi, Jain, and Chan 2013; Gunasekaran, Subramanian, and Rahman 2015; Heckmann, Comes, and Nickel 2015). Therefore, in light of the clear industrial and academic importance of this topic, we investigate how managers based in a European HVM firm operating in an uncertain and dynamic environment evaluate supply chain disturbances. More specifically, this research compares how managers dealing with the overall supply chain and managers dealing with specific products rank disturbance factors when adopting the following two sourcing strategies: (a) insourcing/nearshore outsourcing (i.e. within Europe), and (b) outsourcing/offshoring (specifically to Asia).

The remainder of this paper is organised as follows. A literature review is provided in Section 2 before the research method is outlined in Section 3. Findings are presented in Sections 4, which focuses on the comparison of the disturbance factors related to the firm, the supply network and location, and their relative importance when choosing different sourcing strategies. In Section 5, we illustrate through our case study how HVM firms are mitigating supply chain disturbances through novel methods such as developing specialist clusters, local sourcing and reshoring - before the paper closes with Section 6 'Discussion and conclusions'.

\section{Literature review}

Based on the definition of supply chain disturbances given in the previous section, we used the keywords 'supply chain', 'supply chain risk' or 'supply chain risk management' together with 'risk' or 'uncertainty' to search the literature. The keywords were combined in order to constitute a series of strings (e.g. 'supply chain' AND 'risk') and relevant articles 


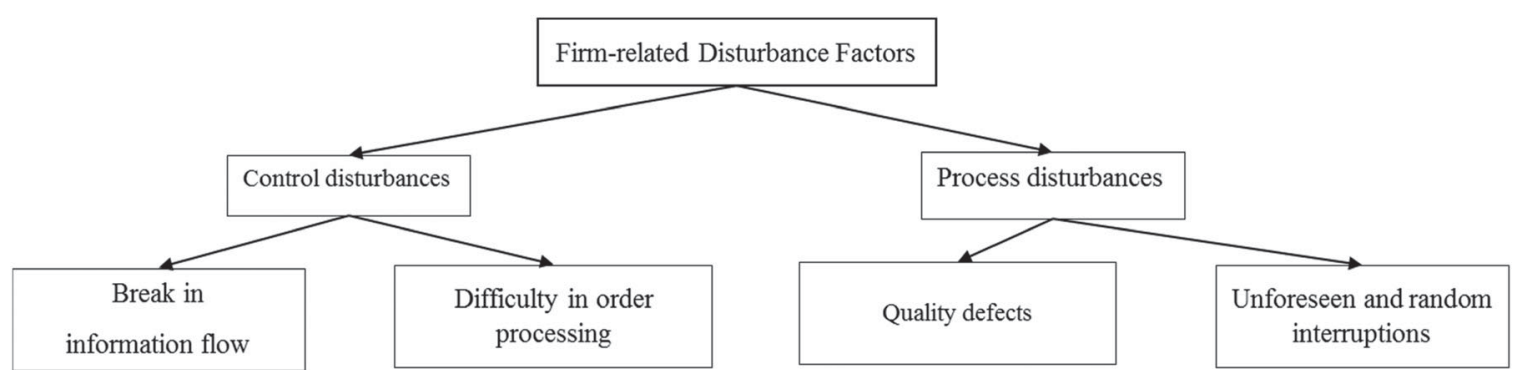

Figure 1. Firm-related disturbance factors.

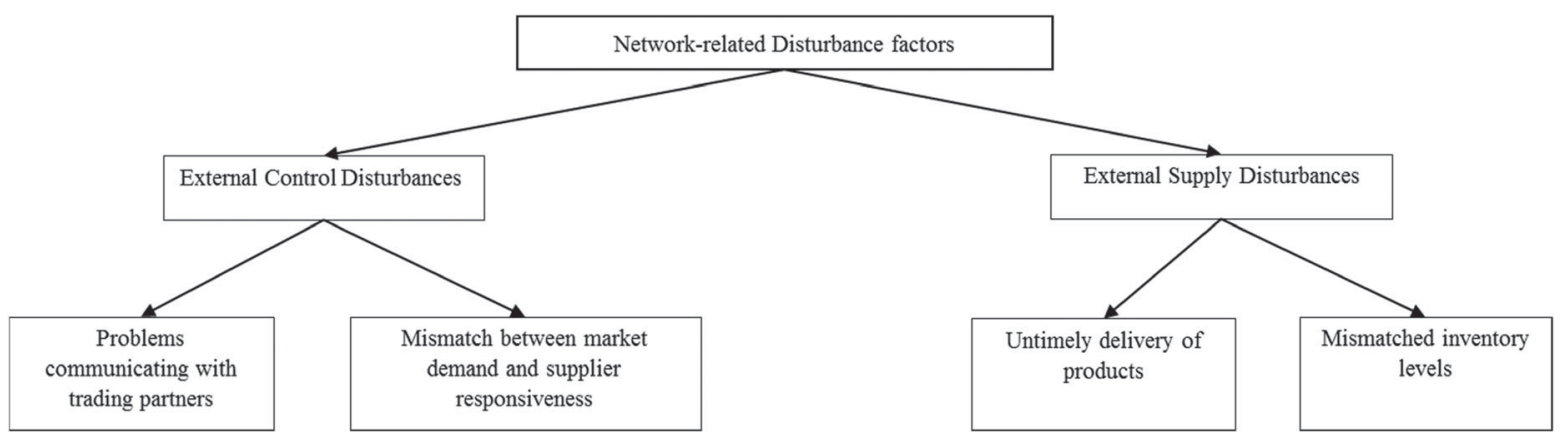

Figure 2. Network-related disturbance factors.

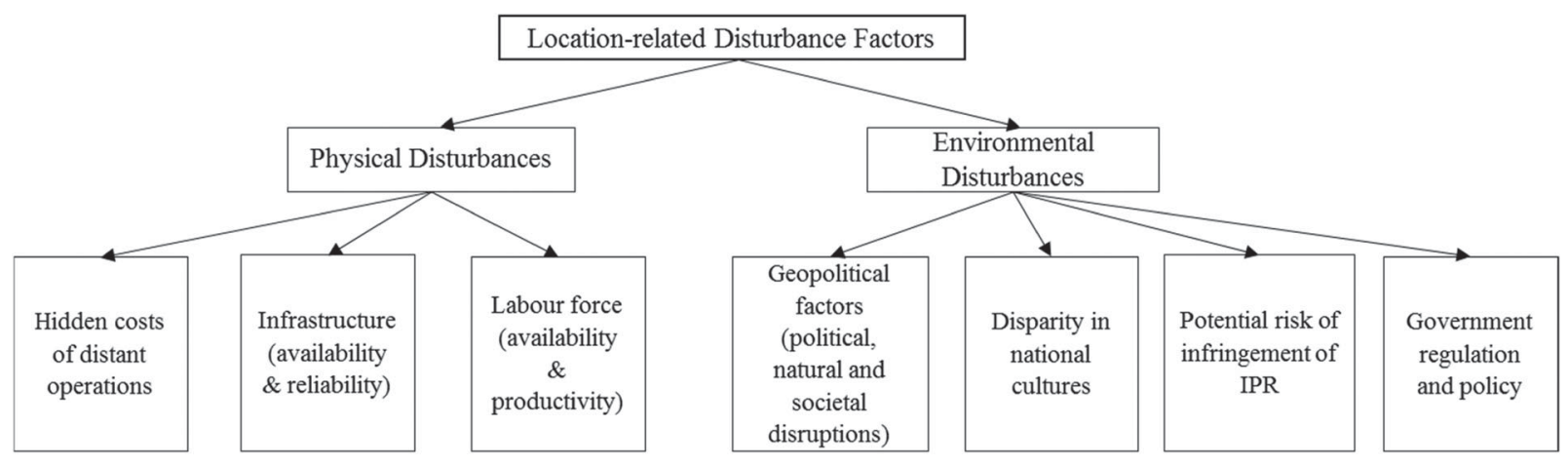

Figure 3. Location-related disturbance factors.

were identified through searches of Business Source Premier, Proquest, Emerald databases, and the Google Scholar search engine. We also supplemented our manual process organically with papers cited by others that are relevant to this study. The literature review provided support for the conceptual models (Figures 123-4) and was used as a foundation to build these. The potential disturbance factors were identified from the literature and grouped into firm-related, network-related and location-related disturbance factors. The aim was to understand the most important supply chain disturbances (risks and uncertainties) that affect HVM firms when adopting the following two sourcing strategies: (a) insourcing/nearshore outsourcing, and (b) outsourcing/offshoring.

\subsection{Supply chain disturbances faced by global HVM firms}

Global HVM firms are characterised by complex network systems, dynamic environments and rapidly changing technologies (Zhang and Gregory 2011), with a common trend towards moving manufacturing to low-cost locations (Zhang, Gregory, and Neely 2016), creating operational challenges when coordinating engineering processes across geographical boundaries. A key factor that distinguishes HVM firms from non-HVM firms is resource scarcity. HVM firms like Rolls-Royce and Pratt \& Whitney (aerospace) or GE Healthcare or Siemens face a scarcity of suppliers, talent and raw materials, unlike non-HVM 


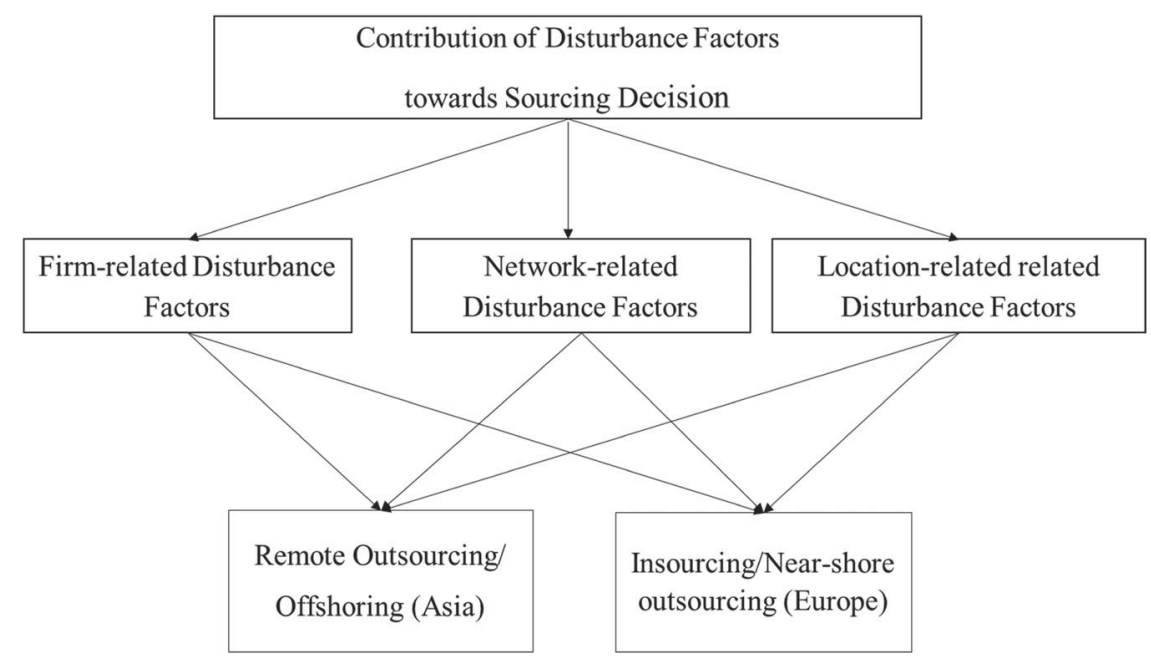

Figure 4. Sourcing strategies taking account of disturbance factors.

firms like Levi's or Nike (brand retailers). The distribution of activities and scarcity of resources increase the vulnerability of HVM firms' globally dispersed supply chains.

Managers are pushed to show the short-term benefits of operating a dispersed supply chain, principally in the form of greater profits, new products and increased sales, but are generally unaware of the key disturbance factors and do not fully realise the importance of preventing them or at least mitigating their negative impact (Baryannis et al. 2019). Therefore, it becomes essential to identify the risks and uncertainties facing the supply chains of HVM firms. Risks and uncertainties are distinguished by the fact that uncertainty cannot be expressed in terms of numerical probabilities, whereas risk can. In this research, the two are combined and termed 'disturbance factors'. Disturbance factors have the undesired properties of randomness and provoke disruptions in the operations process and so affect the final customer (Huq, Pawar, and Rogers 2016; Ivanov et al. 2017). It might also cause a ripple effect, with the disturbance propagating throughout the supply chain and thus impacting performance at multiple tiers (Dolgui, Ivanov, and Sokolov 2018; Mishra et al. 2019).

Categorising disturbance (or risk/uncertainty) factors is not a common approach in the literature on supply chain risk. Ho et al. (2015) found that out of 224 reviewed articles on supply chain risk management, only 20 categorised the risk factors. One of the most comprehensive and widely used approaches is the classification applied by Christopher and Peck (2004), which divides risks according to the source, that is, internal to the firm, internal to the network while being external to the firm, and external to the network (Samvedi, Jain, and Chan 2013). Using a similar approach, in the present study the sources of disturbances that would hinder optimal supply chain performance of a global HVM firm were identified by an extensive literature review and grouped into three broad categories: (1) firm-related, (2) network-related and (3) location-related disturbance factors. The objective was to create a comprehensive classification.

\subsection{Location-related disturbance factors}

Location-related disturbance factors can also be divided into two main types, as summarised below and in Figure 3.

\subsubsection{Physical disturbances}

These can directly impact on production's operations and delivery.

(i) There are numerous costs related to distant operations (e.g. corruption, bureaucracy, reduced flexibility), which can be hidden and difficult to measure (Huq, Stevenson, and Zorzini 2014; U.S. Department of Commerce 2016). Also, the relative increase in wages in low-cost distant countries needs to be recognised. For example, the average annual increase in labour costs in China was $13.7 \%$ between 2000 and 2014, whereas in the US it was only 2.9\% (U.S. Department of Commerce 2016). These trends may well lead companies to reconsider their sourcing decisions by moving some activities closer to home and to have fewer major production locations.

(ii) Offshore operations are more likely to see problems related to the availability and reliability of infrastructure (Truong Quang and Hara 2018), such as airport capacity and roads, as well as the reliability of third-party logistics 
and transportation costs. This is more true of India, for example, while China has a sophisticated transport system (Pawar and Rogers 2013).

(iii) Lastly, international location decisions are influenced by the quality and availability of the labour force (Maccarthy and Atthirawong 2003). A firm setting up a manufacturing plant in a Third World country to take advantage of lower labour costs must assess whether the non-availability of skilled personnel may erode its capability to compete on time or efficiency (Bhatnagar and Sohal 2005). For instance, plant location decisions that ignore the skill levels of the local workforce (e.g. level of education or ability to communicate), labour turnover and risks of labour unrest could lead to supply chain disturbances.

\subsubsection{Environmental disturbances}

These have a low probability of occurring, yet often have serious consequences (Truong Quang and Hara 2018; Ivanov and Dolgui 2019; Olivares-Aguila and Elmaraghy 2020). We consider four types of disturbance in this subcategory.

(i) Geopolitical disturbances can be political (e.g. Brexit, trade tariffs), natural (e.g. tsunami, earthquakes) or social (e.g. terrorist attacks, riots). They include revolutions and wars. Each political area or border that a supply chain must cross can pose problems.

(ii) Cultural disparities across borders (Huq, Stevenson, and Zorzini 2014) can increase an MNC's risk owing to the increased organisational complexity. There is also uncertainty related to operating in new markets. For example, written contracts may have different interpretations in other cultures. Moreover, different holiday seasons (e.g. Eid, Christmas, Diwali and Chinese New Year) and different time zones can affect supply chain coordination.

(iii) The risks of infringement of intellectual property rights (IPR) increases with outsourcing. This is a critical issue in highly sensitive industries such as software, pharmaceuticals and aerospace (Huq, Pawar, and Rogers 2016). For example, IBM, Intel and Apple increased the opportunity for their competitors when they outsourced critical elements of their businesses.

(iv) Finally, changes in government regulations and policies can pose significant disturbances (Rangel, Oliveira, and Leite 2015). For example, different regions have different safety and compliance requirements (Huq and Stevenson 2018).

\subsection{Firm-related disturbance factors}

Firm-related disturbance factors are highly linked with internal operational disruptions, consisting mainly of control and process failures (Spiegler, Naim, and Wikner 2012; Aqlan and Lam 2015; Rangel, Oliveira, and Leite 2015). Two subcategories of these factors are briefly described below and the factors are summarised in Figure 1.

\subsubsection{Control disturbances}

These disrupt the flow of information within the firm and the ability to communicate customers' orders (Huq, Pawar, and Rogers 2016). This can occur between divisions and branches, causing many control issues such as (i) break in information flow, which can cause disturbances such as firms being unable to align batch sizes and safety stocks with demand and (ii) poor coordination in order processing.

\subsubsection{Process disturbances}

These hinder the firm's ability to hit delivery targets and reduce flexibility, creating capacity constraints. Causes of such disturbances include random stoppages in manufacturing processes, machine breakdown (Samvedi, Jain, and Chan 2013), as well as defective production (Aqlan and Lam 2015). Therefore, the main process disturbances considered in the framework are (i) quality defects and (ii) unforeseen and random interruptions in manufacturing processes.

\subsection{Network-related disturbance factors}

Network-related disturbances are internal to the network while being external to the firm (Christopher and Peck 2004). This type of risk can emerge at any of the nodes and arcs of the network (Kim, Chen, and Linderman 2015) and is considered difficult to manage as these risks are external to the focal firm (Huq, Pawar, and Rogers 2016). We consider the following two subcategories of these factors, as summarised in Figure 2. 


\subsubsection{External control disturbances}

Focal firms must be aware of possible disruptions that may affect the flow of materials and information between every node in the network (Christopher and Peck 2004). Networks can be financial, informational, relational and innovational (Heckmann, Comes, and Nickel 2015). Poor alignment and lack of integration between communication channels along with other control issues increase vulnerability as well as the severity of disturbances (Rogers, Pawar, and Braziotis 2012). Issues such as transmission of false data can have a knock-on effect and undesirable consequences on all network partners. For example, communicating wrong demand patterns can disturb control activities within the network (Lee, Padmanabhan, and Whang 1997). The two main control disturbance factors are (i) problems communicating with trading partners and (ii) mismatch between market demand and supplier responsiveness (Samvedi, Jain, and Chan 2013; Aqlan and Lam 2015; Huq, Pawar, and Rogers 2016).

\subsubsection{External supply disturbances}

External supply disturbances (i.e. failure in the upstream flow of materials) have increased as a result of globalisation (Samvedi, Jain, and Chan 2013). The two main supply disturbances are: (i) untimely delivery, which is defined as a difference between planned and actual lead times (Lockamy and Mccormack 2010) and (ii) mismatched inventory levels, which can be in the form of excess inventory or shortages of materials (Aqlan and Lam 2015).

\subsection{Sourcing strategies}

Global firms face an ongoing challenge while considering appropriate sourcing decisions and mitigation strategies (Bier, Lange, and Glock 2020), given the different disturbance factors identified above. Sourcing decisions should focus on value maximisation, considering the cost and benefits of each alternative simultaneously (Gray et al. 2013; Tate and Bals 2017). Therefore, it is critical to understand the relevance of different supply chain disturbance factors while considering different sourcing options (Figure 4). In this study, we consider the main two sourcing strategies of a large European-based HVM firm and assess how managers dealing with specific products and managers responsible for wider supply chain issues rank disturbance factors.

The first strategy that we consider is remote outsourcing/offshoring (Asia). Outsourcing can be defined as the performance of supply chain activities by third parties that are not part of the firm's employee base, with the aim achieving cost efficiency and competitiveness (Kremic, Tukel, and Rom 2006; Ellram, Tate, and Billington 2008). In this study, we consider the disturbance factors faced by a European focal firm when it sources a certain input from outside the parent firm's national borders and the site is comparatively remote (specifically Asia in this firm's case). Offshoring here is only geographical, in that the focal firm, in fact, owns and runs the factory (Foerstl, Kirchoff, and Bals 2016; Huq, Pawar, and Rogers 2016).

The second sourcing strategy is insourcing/nearshore outsourcing (Europe). Nearshore outsourcing, or 'nearshoring', occurs when firms use closer locations (nearby countries) or domestic suppliers to undertake supply chain activities (Tate and Bals 2017). Insourcing is where a firm's production activities are performed with its in-house capabilities (Gray et al. 2013). Bringing production closer to home may reduce the location-related disturbances noted above.

\section{Methodology}

We conducted a case study of a large global HVM firm operating in the aerospace industry with annual turnover of more than $£ 10$ billion in 2017 - anonymised here as SpaceCo. Single cases are appropriate for exploratory studies, where the objective is to gain an in-depth understanding (Meredith 1998). By combining multiple data sources, triangulation of methods (AHP and interviews), formulation of an optimisation model to select the most preferable outsourcing strategy and detailed case study analysis of the mitigation of supply chain disturbance factors (in Section 5), we were able to achieve a degree of analytical generalisation and validity inference. Furthermore, it has been suggested that the combination of different methodologies while studying supply chain disturbances, will lead to more accurate managerial insights and better mitigation strategies (Xu et al. 2020).

First, the 15 disturbance factors identified from the literature review were grouped into firm-related, network-related and location-related factors. We then used the Analytic Hierarchy Process (AHP) (Saaty 1980) to evaluate the importance of each disturbance factor with respect to sourcing decisions. AHP allows a set of complex issues, factors and relationships, which have an impact on an overall objective, to be compared in terms of their impacts on the solution to the problem (Saaty 1980). AHP is commonly used to prioritise factors and select best alternatives (Subramanian and Ramanathan 2012). It has been proposed that AHP is an appropriate method to assess supplier sourcing decisions and risks along with other models such as Data Envelopment Analysis (Wu, Luo, and Olson 2014) and Fuzzy AHP (Majumdar et al. 2020). AHP has proved 
valuable to managers who need to assess complex problems in the most rational, systematic and consistent way, without compromising any fundamental component of the decision-making process (Dong and Cooper 2016).

The AHP questionnaires were sent out to two groups of managers within the case firm. The first group comprised three managers whose primary focus was at the product level (e.g. the New Product Introduction Manager). The second group comprised four senior managers concerned with the functioning of the supply chain (e.g. Head of Supply Chain Planning and Control Department). Although of course there was some overlap, the managers in the first group focused on internal company affairs (e.g. improving productivity, maintaining quality) whereas the managers in the second group focused on external issues (e.g. sourcing of components, transportation of goods). The participants were carefully selected and were all well established in their professional fields and had substantial experience (at least five years) of sourcing both within and outside Europe. Our objective was to reveal any differences in their prioritisation of supply chain disturbances.

Since the case study has seven respondents, we used geometric means to convert their ratings into a single rating for pairwise comparison, as per Saaty's (1980) recommendation. The main constraint of AHP is that it is a subjective model, in that it is based on the opinions of decision makers. To avoid biases, we triangulated their views using data from secondary sources such as firm websites, annual reports and other financial reports to verify the importance of disturbance factors during critical periods (Patton 2002). One of the common issues with using AHP is the potential for arbitrary judgement of the decision-maker. However, we confirm consistency by validating the results and through follow-up interviews, which build on the managerial judgements, thus minimising potential bias. The application of AHP involved the following four structured steps (Ramanathan 2006; Ho 2008).

\subsection{Step 1: structuring the assessment problem into a hierarchical model}

Our AHP model has three levels. At the first level of the hierarchy, firm-related disturbance factors, network-related disturbance factors and location-related disturbance factors are our major criteria. These are subcategorised at the second level. At the third level are the two sourcing strategies.

\subsection{Step 2: pairwise comparisons and the judgement matrix}

In this step, the criteria for the factors at each level are compared with respect to a specific criterion at the level immediately above. The resulting weights of the criterion are referred as the local weights. Criteria are compared pairwise and judgements on comparative attractiveness of criteria are captured using Saaty's 1-9 rating scale (Saaty 1980), where $1=$ 'Equal importance', $2=$ 'Equal to moderate importance', $3=$ 'Moderate importance', $4=$ 'Moderate to strong importance', $5=$ 'Strong importance', $6=$ 'Strong to very strong importance', $7=$ 'Very strong or demonstrated importance', 'Very strong to extreme importance', and $9=$ 'Extreme importance'.

We asked each respondent to compare the significance of each disturbance factor against all the others at the same level with respect to a specific criterion in the level immediately above, while considering one of two sourcing strategies: outsourcing/offshoring or insourcing/nearshore outsourcing. Following the completion of the questionnaire, Expert Choice software was used to construct an individual pairwise comparison matrix for ranking the criteria with respect to the goal, and the sub-criteria with respect to the criteria. Overall, a criterion receiving a higher rating is viewed as superior to (or more attractive than) one that receives a lower rating. We followed all the rules suggested by Saaty, such as transitivity property and consistency of matrix, to construct the pairwise comparison matrices. Since human judgements need not be always consistent, we checked for consistency of pairwise comparison matrices and ensured our consistency ratios were below 0.1 (see Saaty 1980).

We followed the rules suggested by Saaty (1980). Each pairwise matrix is formed by comparing the row element by column element

$$
A=\left(a_{i j}\right)\left(i, j=\text { number of criteria } ; a_{i j}>0 ; a_{i j}=\frac{1}{a_{j i}} ; a_{i i}=1 \text { for all } i\right)
$$

Consistency ratio $(\mathrm{CR})=$ Consistency Index $(\mathrm{CI}) /$ Random Index $(\mathrm{RI})$, Consistency Index $(\mathrm{CI})=\frac{\left(l a m b d a_{\max }-n\right)}{(n-1)}(n=$ Size of matrix).

$$
\left(A=\text { pairwise matrix } \text { lamda } \text { lax }_{2}=\text { largest eignevalue of } A\right)
$$


Table 1. Respondent and interviewee profile.

\begin{tabular}{|c|c|c|c|c|c|}
\hline & Position & $\begin{array}{c}\text { Work } \\
\text { Experience }\end{array}$ & Education & Age (years) & $\begin{array}{c}\text { Interview } \\
\text { Duration } \\
(2015-2017)\end{array}$ \\
\hline \multirow[t]{3}{*}{ Product managers } & $\begin{array}{l}\text { Programme Man- } \\
\text { ager [Product X } \\
\text { (anonymized)] }\end{array}$ & 16-20 years & Post-graduate & $30-40$ & $\begin{array}{l}\text { Three } 1 \text {-hour meetings } \\
\text { over } 9 \text { months }\end{array}$ \\
\hline & $\begin{array}{l}\text { New Product Introduction } \\
\text { Manager }\end{array}$ & $>20$ years & $\begin{array}{l}\text { Post-graduate (SCM } \\
\text { specialisation) }\end{array}$ & $40-50$ & $\begin{array}{l}\text { Nine 1-hour meetings } \\
\text { over } 23 \text { months }\end{array}$ \\
\hline & Production Manager & $8-10$ years & $\begin{array}{l}\text { Post-graduate } \\
\text { (SCM/Logistics } \\
\text { specialisation) }\end{array}$ & $40-50$ & $\begin{array}{l}\text { Two 1-hour meetings } \\
\text { over } 2 \text { months }\end{array}$ \\
\hline \multirow[t]{4}{*}{ Supply chain managers } & Supply Chain Manager & $11-15$ years & Post-graduate & $30-40$ & $\begin{array}{l}\text { Two 1-hour meetings } \\
\text { over } 2 \text { months }\end{array}$ \\
\hline & $\begin{array}{l}\text { Supply Chain Projects } \\
\text { Manager }\end{array}$ & 16-20 years & $\begin{array}{l}\text { Post-graduate (SCM \& } \\
\text { Industrial Management } \\
\text { specialisation) }\end{array}$ & $40-50$ & $\begin{array}{l}\text { Five } 1 \text {-hour meetings } \\
\text { over } 7 \text { months }\end{array}$ \\
\hline & $\begin{array}{l}\text { Head of Supply Chain } \\
\text { Planning and Control } \\
\text { Department }\end{array}$ & $>20$ years & $\begin{array}{l}\text { Post-graduate (SCM } \\
\quad \& \text { Manufactur- } \\
\text { ing Management } \\
\text { specialisation) }\end{array}$ & $40-50$ & One 1-hour meeting \\
\hline & $\begin{array}{l}\text { Senior Procurement } \\
\text { Manager }\end{array}$ & 16-20 years & $\begin{array}{l}\text { Post-graduate (Project } \\
\text { Management } \\
\text { specialisation) }\end{array}$ & $30-40$ & Email exchanges \\
\hline
\end{tabular}

\subsection{Step 3: Weight computation}

Weights of criteria are computed using the Eigen vector method and we used Expert Choice software to calculate the local weights. The normalised Eigen vector corresponding to the principal Eigen value of the judgement matrix provides the Eigen value of each criterion.

Local weights are estimated following Saaty (1980):

$$
A w=\text { Lambda }_{\max } w\left(A=\text { pairwise matrix } ; \text { lamda } a_{\max }=\text { largest eignevalue of } A ; w=\right.\text { normalised weights }
$$

\subsection{Step 4: best alternatives}

Final weights of alternatives are computed by aggregating local weights of criteria and local weights of alternatives with respect to an individual criterion. We used the equation from Ramanathan (2006) to arrive at final weights of alternatives.

Final weights of alternative:

$$
A_{1}=\sum_{j}\left[\left(\text { Local weight of } A_{1} \text { with respect to criterion } C_{j}\right) \times\left(\text { Local weight of } C_{j}\right)\right]
$$

During 2015-2017, we interviewed the seven AHP respondents multiple times to gain an in-depth understanding of the phenomena (see Table 1). Because there are relatively few global HVM firms, the multiple perspectives from different supply chain levels within one firm are likely to be reasonably representative of the industry as a whole, and generalisable; this rationale has been followed in several previous cases and AHP studies in either developing or validating a framework (Ramanathan 2013; Subramoniam et al. 2013). In addition to the managers participating in the AHP study, two other managers - the Head of Purchasing and the Strategic Purchasing Executive - were interviewed to corroborate the findings.

The results of the AHP were shared with the managers and their comments and feedback gathered. The respondents' validation of the findings strengthens the robustness of our weighting process. At the follow-up, we asked how they would manage/mitigate these kinds of disturbances, for example, whether any of these disturbance factors would influence their reshoring decisions.

Finally, to check the robustness of the decisions we carried out a sensitivity test by reducing the dominating factor value by $20 \%$. The rationale for this is derived from the Pareto analysis, which states that $20 \%$ of issues will have $80 \%$ impact. Overall, we did not find a significant change in the sourcing decisions of the two categories of managers. 
Table 2. Priority comparison of firm-related disturbance factors.

\begin{tabular}{lccccc}
\hline & \multicolumn{2}{c}{ Product managers } & & \multicolumn{2}{c}{ Supply chain managers } \\
\cline { 2 - 3 } \cline { 5 - 6 } Firm-related Disturbances & $\begin{array}{c}\text { Outsource/offshore } \\
\text { (Asia) }\end{array}$ & $\begin{array}{c}\text { Insource/near-shore } \\
\text { outsource (Europe) }\end{array}$ & & $\begin{array}{c}\text { Outsource/offshore } \\
\text { (Asia) }\end{array}$ & $\begin{array}{c}\text { Insource/near-shore } \\
\text { outsource (Europe) }\end{array}$ \\
\hline Control disturbances & $\mathbf{3 9 . 3 \%}$ & $\mathbf{1 1 . 8 \%}$ & & $\mathbf{1 9 . 8 \%}$ & $\mathbf{4 . 1 \%}$ \\
Break in information flow & $9.8 \%(3=4)$ & $2.0 \%(7)$ & & $3.8 \%(5)$ & $0.7 \%(8)$ \\
Difficulty in order processing & $29.5 \%(2)$ & $9.8 \%(3=4)$ & & $16.0 \%(2)$ & $3.4 \%(7)$ \\
Process disturbances & $\mathbf{3 9 . 4 \%}$ & $\mathbf{9 . 4 \%}$ & & $\mathbf{6 4 . 3 \%}$ & $\mathbf{1 1 . 9 \%}$ \\
Quality defects & $6.6 \%(6)$ & $1.8 \%(8)$ & & $14.3 \%(3)$ & $3.6 \%(6)$ \\
Unforeseen and random interruptions & $32.8 \%(1)$ & $7.6 \%(5)$ & & $50.0 \%(1)$ & $8.3 \%(4)$ \\
Total & $\mathbf{7 8 . 7 \%}$ & $\mathbf{2 1 . 3 \%}$ & & $\mathbf{8 4 . 0 \%}$ & $\mathbf{1 6 . 0 \%}$ \\
\hline
\end{tabular}

Note: The rankings of the factors for each group of Manager is given in parentheses.

\section{Findings}

\subsection{Comparison of firm-related disturbance factors}

The factors ranked first and second in importance in making sourcing decisions are unforeseen and random interruptions and difficulty in order processing when the strategy is outsource/offshore (Asia), for both product managers and supply chain managers (see Table 2). According to the New Product Introduction Manager (internal facing) and the Physical Logistics Manager (external facing), factors like these which might affect delivery performance are critical and can influence their decision to reshore or to near-shore.

An interesting difference between the two groups concerned quality defects. When the strategy is outsource/offshore (Asia), quality defects are ranked third by supply chain managers and sixth by product managers. Supply chain managers feel more responsible when sourcing from distant locations, since if anything goes wrong in terms of quality they get the blame. Conversely, quality defects are not a significant disturbance factor for either group when insourcing or outsourcing near-shore (Europe), which shows that they are more confident when they have more visibility and control.

Break in information flow is considered a bigger problem when outsourcing or offshoring by both groups of managers. The Head of the Supply Chain Planning and Control Department remarked: 'Interesting results, with some clear distinctions between internally and externally focused groups of managers. [However] I would have expected disturbances relating to breaks in information flow to be more evident [when the strategy is near-shore insourceloutsource] .... .'

Difficulty in order processing while insourcing or nearshore outsourcing is ranked higher by supply chain managers. An explanation for this might be that since product managers are internally facing, they do not directly deal with order processing and perceive it to be more of a challenge than externally facing supply chain managers.

\subsection{Comparison of network-related disturbance factors}

Communication problems when outsourcing or offshoring was the number one disturbance for both groups of managers (see Table 3). The Head of Supply Chain Planning and Control Department agreed with our results and commented:

Yes, the supply network disturbances seem to be more sensitive to how distant the supplier is away from you. So the more time zones separating you [and the supplier], the more likely [it is] that any discontinuities in information or communication flows [will] affect the supply.

The second biggest disturbance factor was communication problems while insourcing or outsourcing nearshore for managers responsible for wider supply chain issues. The Senior Procurement Manager explained that communication problems while sourcing within Europe should not be underestimated:

I think the level of miscommunication can trip you up in similar ways as on offshore sourcing [Asia] ... If these disturbances occur, the expectations most times don't match and to get them aligned and back to a necessary level is of course a huge effort.

The Head of Purchasing mentioned problems due to a failure to have the work instructions properly translated into the local language, which led to penalty charges for late delivery of a critical product to a customer.

On the other hand, for internally facing product managers, untimely delivery of products was ranked second while outsourcing or offshoring to Asia, but only fifth when insourcing or outsourcing nearshore (to Europe). The delivery of products is a key function of product managers, while communication is a key issue for supply chain managers. It seems that their perception of the importance of supply-related disturbance factors was closely tied to their key functions. 
Table 3. Priority comparison of network-related disturbance factors.

\begin{tabular}{|c|c|c|c|c|}
\hline \multirow[b]{2}{*}{ Network-related disturbances } & \multicolumn{2}{|c|}{ Product managers } & \multicolumn{2}{|c|}{ Supply chain managers } \\
\hline & $\begin{array}{l}\text { Outsource/offshore } \\
\text { (Asia) }\end{array}$ & $\begin{array}{l}\text { Insource/near-shore } \\
\text { outsource (Europe) }\end{array}$ & $\begin{array}{l}\text { Outsource/offshore } \\
\text { (Asia) }\end{array}$ & $\begin{array}{l}\text { Insource/near-shore } \\
\text { outsource (Europe) }\end{array}$ \\
\hline External control disturbances & $57.0 \%$ & $19.05 \%$ & $66.0 \%$ & $16.4 \%$ \\
\hline $\begin{array}{l}\text { Mismatch between market } \\
\text { demand and supplier } \\
\text { responsiveness }\end{array}$ & $10.8 \%(4)$ & $3.6 \%(6)$ & $12.6 \%(3)$ & $3.0 \%(6)$ \\
\hline Communication problems & $46.2 \%(1)$ & $15.4 \%(3)$ & $53.4 \%(1)$ & $13.4 \%(2)$ \\
\hline External supply disturbances & $19.0 \%$ & $5 \%$ & $13.9 \%$ & $3.8 \%$ \\
\hline Mismatched inventory levels & $2.9 \%(7)$ & $1.3 \%(8)$ & $2.3 \%(7)$ & $0.7 \%(8)$ \\
\hline Untimely delivery of products & $16.1 \%(2)$ & $3.7 \%(5)$ & $11.6 \%(4)$ & $3.1 \%(5)$ \\
\hline Total & $76.0 \%$ & $24.0 \%$ & $79.9 \%$ & $20.1 \%$ \\
\hline
\end{tabular}

Note: The rankings of the factors for each group of Manager is given in parentheses.

Table 4. Priority comparison of location-related disturbance factors.

\begin{tabular}{|c|c|c|c|c|}
\hline \multirow[b]{2}{*}{ Location-related disturbances } & \multicolumn{2}{|c|}{ Product managers } & \multicolumn{2}{|c|}{ Supply chain managers } \\
\hline & $\begin{array}{l}\text { Outsource/offshore } \\
\text { (Asia) }\end{array}$ & $\begin{array}{l}\text { Insource/near-shore } \\
\text { outsource (Europe) }\end{array}$ & $\begin{array}{l}\text { Outsource/offshore } \\
\text { (Asia) }\end{array}$ & $\begin{array}{l}\text { Insource/near-shore } \\
\text { outsource (Europe) }\end{array}$ \\
\hline Environmental disturbances & $30.4 \%$ & $6.5 \%$ & $16.4 \%$ & $2.6 \%$ \\
\hline Disparity in national cultures & $8.6 \%(4=5)$ & $2.4 \%(10)$ & $4.5 \%(5)$ & $0.9 \%(11)$ \\
\hline Geopolitical factors & $17.2 \%(2)$ & $3.4 \%(8=9)$ & $9.3 \%(4)$ & $1.4 \%(9)$ \\
\hline Regulatory and policy factors & $1.2 \%(11)$ & $0.2 \%(14)$ & $0.8 \%(12)$ & $0.1 \%(14)$ \\
\hline Infringement of IPR & $3.4 \%(8=9)$ & $0.5 \%(13)$ & $1.8 \%(8)$ & $0.2 \%(13)$ \\
\hline Physical disturbances & $48.7 \%$ & $14.4 \%$ & $65.6 \%$ & $15.4 \%$ \\
\hline Hidden costs & $30.9 \%(1)$ & $8.6 \%(4=5)$ & $45.4 \%(1)$ & $10.1 \%(3)$ \\
\hline Infrastructure & $14.0 \%(3)$ & $4.7 \%(6)$ & $15.8 \%(2)$ & $4.2 \%(7)$ \\
\hline Labour force & $3.8 \%(7)$ & $1.1 \%(12)$ & $4.4 \%(6)$ & $1.1 \%(10)$ \\
\hline Total & $79.2 \%$ & $20.8 \%$ & $82.0 \%$ & $18.0 \%$ \\
\hline
\end{tabular}

Note: The rankings of the factors for each group of Manager is given in parentheses.

We also found that mismatched inventory levels when insourcing or outsourcing nearshore was the lowest-ranked disturbance for both groups (ranked 8), while it the second lowest (ranked 7) when outsourcing or offshoring. According to the Head of Supply Chain Planning and Control Department, this should have generally been ranked higher and was a bigger problem when outsourcing or offshoring was taking place in Asia. It was his view that 'the total inventory at vendor, in transit and in the business, would need to be considered'.

\subsection{Comparison of location-related disturbance factors}

Both groups of managers rank the hidden costs of distant operations while outsourcing or offshoring to Asia as the highest location-related disturbance factor (see Table 4). There can be many causes of hidden costs, such as exchange rate appreciation, high utilities and transport costs (driven by rising fuel prices) and wage inflation (particularly in China). For example, between 2005 and 2016, the average wage bill in China's manufacturing sector trebled to \$3.6 (Euromonitor International 2017). If this trend continues, then by 2020 US wages will be only about four times higher than Chinese wages, compared with 20 times higher in 2008 (United States Department of Commerce 2017). This changing calculus means that companies that made the sourcing decision 10-15 years ago may need to reconsider. In relation to exchange rates, SpaceCo works very closely with its treasury department to ensure that the level of disturbance is clearly understood before embarking on a sourcing project.

Geopolitical issues are ranked second by product managers and fourth by supply chain managers when the strategy is outsource/offshore (Asia) out of the 15 factors, indicating that they are quite high on their agenda. Political instability within an area can affect the physical assets, personnel and operations of foreign firms. It may be hard to adjust the structure or geographical set-up of a supply chain in reaction to changes in the political environment if the firm has plants in another continent, but Brexit and the United States renegotiating the North American Free Trade Agreement (Forbes 2017) show that tighter border controls and tariffs may emerge even within continents. Firms have to navigate an ever-changing regulatory 
Table 5. Comparison of overall weights of firm-, network- and location-related disturbance factors and preferred sourcing decision.

\begin{tabular}{lcc}
\hline & Product managers & Supply chain managers \\
\hline Firm-related & & $84.0 \%$ \\
Outsource/Offshore (Asia) & $78.7 \%$ & $16.0 \%$ \\
Insource/Nearshore Outsource (Europe) & $21.3 \%$ & $79.9 \%$ \\
Network-related & & $20.1 \%$ \\
Outsource/Offshore (Asia) & $76.0 \%$ & $82.0 \%$ \\
Insource/Nearshore Outsource (Europe) & $24.0 \%$ & $18.0 \%$ \\
Location-related & & \\
Outsource/Offshore (Asia) & $79.2 \%$ & $15.7 \%$ \\
Insource/Nearshore Outsource (Europe) & $20.8 \%$ & $84.3 \%$ \\
Preferred Sourcing decision & & $20.9 \%$ \\
Outsource/Offshore (Asia) & $79.1 \%$ & \\
Insource/Nearshore Outsource (Europe) & & \\
\hline
\end{tabular}

Table 6. Effect of disturbance factors on outsourcing strategies.

\begin{tabular}{|c|c|c|c|c|c|c|}
\hline \multirow[b]{2}{*}{$\begin{array}{l}\text { Disturbance } \\
\text { factors } \\
\text { Outsourcing } \\
\text { strategies } \\
\left(\mathrm{OS}_{1}\right)\end{array}$} & \multicolumn{2}{|c|}{$\begin{array}{c}\text { Firm level } \\
\text { disturbance factor } \\
\left(\mathrm{FD}_{\mathrm{i}}\right)\end{array}$} & \multicolumn{2}{|c|}{$\begin{array}{c}\text { Network level } \\
\text { disturbance factor } \\
\left(\mathrm{ND}_{\mathrm{j}}\right)\end{array}$} & \multicolumn{2}{|c|}{$\begin{array}{l}\text { Location related } \\
\text { disturbance factor } \\
\left(\mathrm{LD}_{\mathrm{k}}\right)\end{array}$} \\
\hline & $\begin{array}{c}\text { Control } \\
\text { disturbances } \\
\left(\mathrm{FD}_{1}\right)\end{array}$ & $\begin{array}{c}\text { Process } \\
\text { disturbances } \\
\left(\mathrm{FD}_{2}\right)\end{array}$ & $\begin{array}{c}\text { External } \\
\text { control } \\
\text { disturbances } \\
\left(\mathrm{ND}_{1}\right)\end{array}$ & $\begin{array}{c}\text { External } \\
\text { supply } \\
\text { disturbances } \\
\left(\mathrm{ND}_{2}\right)\end{array}$ & $\begin{array}{c}\text { Physical } \\
\text { disturbances } \\
\left(\mathrm{LD}_{1}\right)\end{array}$ & $\begin{array}{l}\text { Environmental } \\
\text { disturbance } \\
\left(\mathrm{LD}_{2}\right)\end{array}$ \\
\hline $\begin{array}{l}\text { Outsource/Offshore }\left(\mathrm{OS}_{1}\right) \\
\text { Insource/Near-shore Outsource }\left(\mathrm{OS}_{2}\right)\end{array}$ & $\begin{array}{l}\mathrm{OS}_{1} * \mathrm{FD}_{1} \\
\mathrm{OS}_{2} * \mathrm{FD}_{1}\end{array}$ & $\begin{array}{l}\mathrm{OS}_{1} * \mathrm{FD}_{2} \\
\mathrm{OS}_{2} * \mathrm{FD}_{2}\end{array}$ & $\begin{array}{l}\mathrm{OS}_{1} * \mathrm{ND}_{1} \\
\mathrm{CP}_{2} * \mathrm{ND}_{1}\end{array}$ & $\begin{array}{l}\mathrm{OS}_{1} * \mathrm{ND}_{2} \\
\mathrm{OS}_{2} * \mathrm{ND}_{2}\end{array}$ & $\begin{array}{l}\mathrm{OS}_{1} * \mathrm{LD}_{1} \\
\mathrm{OS}_{2} * \mathrm{LD}_{1}\end{array}$ & $\begin{array}{l}\mathrm{OS}_{1} * \mathrm{LD}_{2} \\
\mathrm{OS}_{2} * \mathrm{LD}_{2}\end{array}$ \\
\hline
\end{tabular}

landscape and so need to take consideration of geopolitical and regulatory stability. To help prevent such disturbances, SpaceCo tries to source from politically stable countries and/or ensure that it has a portfolio of suppliers, thus diversifying global operations and spreading risks.

Firms may need to reveal trade secrets, new product development plans and special process techniques while sourcing from partners. This leads to the risk of infringement of IPR, though this was, surprisingly, ranked low in both outsourcing scenarios. The Head of Purchasing cautioned that European firms are concerned about how their intellectual property (IP) might be exploited in China. She mentioned that SpaceCo considers this risk very seriously and is often deterred from sourcing highly complex products in China. To mitigate this kind of location-related disturbance, the firm has strengthened resources to manage patents by creating a global framework of IP officers and procuring a global IT system to make patent information more secure.

\subsection{Comparison of overall weights of firm-, network- and location-related disturbance factors}

We can observe an interesting trend from Table 5. Externally facing supply chain managers consistently rank firm-, networkand location-related disturbances higher when outsourcing/offshoring from Asia and lower when insourcing/nearshore outsourcing from Europe than do internally facing product managers. A reason for this could be that supply chain managers have a better understanding of the disturbances associated with a more dispersed and complex supply chain. The Head of Supply Chain Planning and Control Department tried to explain this phenomenon in these terms: 'I assume that as the supply chain managers are more likely to have to deal with issues relating to failures they give a more realistic view of the outsourceloffshore option than product managers'. It seems more difficult to manage supply chain disturbances the further away they are from the focal company. This is reflected in the preferred sourcing decision of both groups of managers, who overwhelmingly chose the insource/nearshore outsource (Europe) option. Thus, given the disturbances, managers feel that the high level of disturbances while outsourcing/offshoring from Asia will outweigh the cost benefits of sourcing from a low-cost location. 


\subsection{Mathematical model}

In this section, we enumerate a generic mathematical model to capture the influence of disturbance factors on outsourcing strategies. We develop a deterministic model, which represents the preferable outsourcing strategy $\left(\mathrm{OS}_{1}\right)$ with respect to firm, network and location-related disturbance factors. For example, the influence of firm level disturbance on an outsourcing strategy is represented as $\left(O S_{l} * F D_{i}\right)$. The influence of different disturbance factors on both strategies is shown in Table 6. This scenario can be modelled as a multi-objective formulation as shown in the below equation. The model has three disturbance factors in the objective function and as per the conventional way of formulation we try to minimise disturbance factors (Zhang et al. 2015). Our objective is to quantify each outsourcing strategy, considering all factors and sub-factors that are within the acceptable prescribed values. This is a simple formulation, as the model did not include weights for each objective. The weights can be decided based on the requirements of the practitioners. The solutions to the model can be arrived using goal-programming method or heuristics-based methods.

$$
\begin{aligned}
& \begin{array}{ll}
\hline \text { Notations } & \\
i & \text { Firm level disturbance factor index } \\
F D_{i} & \text { Firm level disturbance factors } \\
m & \text { Total number of firm level disturbance factors } \\
j & \text { Network-level disturbance factor index } \\
N D_{j} & \text { Network-level disturbance factors } \\
n & \text { Total number of network-level disturbance factors } \\
k & \text { Location-related disturbance factor index } \\
L D_{k} & \text { Location-related disturbance factor } \\
o & \text { Total number of location-related disturbance factors } \\
l & \text { Strategy indicator } \\
O S_{l} & \text { Outsourcing strategy (OS } 1 \text { - strategy 1, strategy 2) } \\
t & \text { Total number of strategies } \\
X_{O D} & \text { Binary variable } \\
\hline
\end{array} \\
& Z=\operatorname{Min} \sum_{i=F D_{1}}^{F D_{m}} \sum_{l=O S_{1}}^{O S_{t}}\left(O S_{l} * F D_{i} * X_{O D}\right)+\operatorname{Min} \sum_{j=N D_{1}}^{N D_{n}} \sum_{l=O S_{1}}^{O S_{t}}\left(O S_{l} * N D_{i} * X_{O D}\right)+\operatorname{Min} \sum_{k=L D_{1}}^{L D_{o}} \sum_{l=O S_{1}}^{O S_{t}}\left(O S_{l} * L D_{i} * X_{O D}\right)
\end{aligned}
$$

Subject to

$$
\sum_{O S_{1}}^{O S_{t}} X_{O D}=1 \sum_{l=C P_{1}}^{C P_{t}} X_{c p} 1 \text { (One strategy r one disturbance factor) }
$$

$X_{O D} \epsilon[0,1], X_{O D}$ is an integer.

$$
\begin{aligned}
& \left(O S_{l} * F D_{i}\right) \geq \text { min_value } \\
& \left(O S_{l} * N D_{j}\right) \geq \text { min_value } \\
& \left(O S_{l} * L D_{m}\right) \geq \text { min_value }
\end{aligned}
$$

\section{Case study analysis of the mitigation of supply chain disturbance factors}

The sourcing spend in countries outside of its home country for SpaceCo during 2015-2017 was 70\%, of which $15 \%$ was in low-cost countries. This budget was higher than 10 years previously and had been growing consistently. In fact, the company aims to source $40 \%$ of its total spend from low-cost countries by 2025 . As the company's spend with external suppliers is significant, this area is given a lot of attention within the sourcing functions. The main driver of outsourcing/offshoring has been cost savings. For example, SpaceCo's Strategic Purchasing Executive reported that sourcing from low-cost locations in Asia had had a significant $(>15 \%)$ piece-part cost reduction over nearshoring from Europe. The Head of Purchasing added that this is necessary when competing in a global marketplace, as customers in the aerospace industry are primarily concerned with cost, technology and responsiveness. Another benefit of offshoring is the ability to access new markets. SpaceCo predicts that emerging markets in Asia, the Middle East and Africa will experience the fastest rates of growth. 


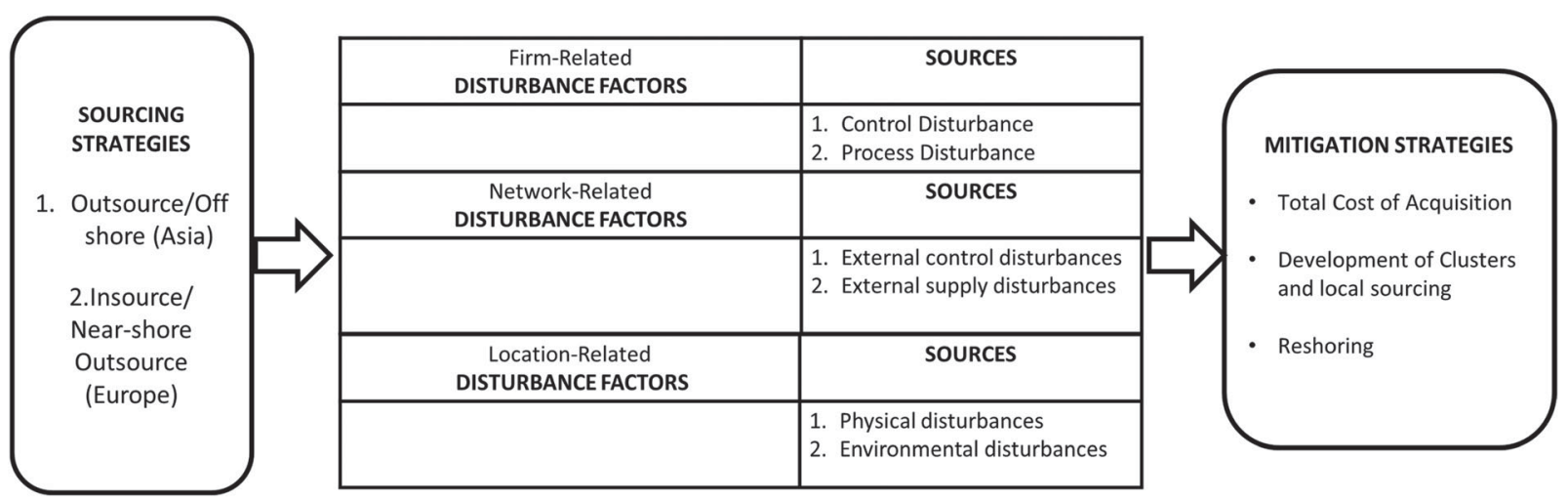

Figure 5. Supply chain disturbance and mitigation framework for HVM firms.

Two of the major factors leading to an increase in demand in these regions include faster GDP growth and retirement of existing units.

Nonetheless, in order to deliver a successful outsourcing or offshoring strategy, firms need to understand the disturbances holistically and design appropriate mitigation plans. Below we describe what SpaceCo does to mitigate disturbances in its supply chain. The information is used to derive the overall framework for HVM firms presented in Figure 5. SpaceCo adopts a robust approach to disturbance mitigation and considers various factors, not only alignment to the cost model.

\subsection{Total cost of acquisition}

In order to mitigate disturbances, SpaceCo considers the total cost of acquisition. It tries to ensure that the cost model and potential disturbances are correctly aligned. For instance, it mitigates disturbances due to lack of availability and quality of infrastructure and the labour force. Where a product has a high labour content, SpaceCo attempts to exploit opportunities available in lower-wage countries. Similarly, for more automated manufacturing processes or complex products, it tries to secure a source in a country which can offer lower costs of capital and the right labour expertise. By being able to hire from the local workforce it can cut down on incidental costs and uncertainty such as arranging visas for expat employees. This method is fluid - if a manufacturing process previously required a high level of manual input but now can be largely automated, the cost focus shifts to the cost of capital as opposed to labour rates.

SpaceCo will source remotely as long as there is a sensible business case based on the total cost of acquisition. While calculating the total cost of acquisition, it considers hidden costs. For example, if the product is bulky and shipping costs are considerable, then it will try to mitigate disturbances by nearshoring rather than remote sourcing. Lead time can also be a challenge when remote offshoring/outsourcing. Even if there is a clear unit cost reduction, SpaceCo will factor in the challenge of transporting the product and any increase in lead time leading to untimely delivery of products. Moreover, increased lead time often results in holding more safety stock and thus more inventories in the pipeline, which represents additional working capital cost. According to the Programme Manager (Product X):

When required we will implement safety stocks; however, this practice is now limited due to the impact on cash flow, [as] our supply chains must be as lean as possible. As a result of this we have seen an increase in airfreight usage compared to sea freight as from a total cost perspective it is cheaper to use air freight than have shipments on the sea.

Thus, the cost benefit of sourcing from low-cost locations has to outweigh the cost of related disturbances, such as working capital tied up in inventory.

SpaceCo conducts rigorous supplier assessments prior to business being undertaken to ensure business continuity and holds follow-up monthly reviews of progress. The Programme Manager (Product X) added: 'Often the cost of onsite resource, the cost of daily calls and expediting is not taken into consideration compared to established European suppliers where this support is not required.' However, the focus is not always on the supplier. According to the Head of Purchasing, another factor SpaceCo considers while calculating total cost is 'closeness to customer'. By being closer to the customer, it can develop stronger relationships with that customer, which helps reduce total cost. It will also weigh the level of local government support before deciding the sourcing strategy. For example, its decision to insource turbine blade castings was driven by the incentives (e.g. tax benefits) offered by the government. 


\subsection{Development of clusters and local sourcing}

Currently, over half of SpaceCo's order book is from the Middle East and Asia. In order to be close to customers, SpaceCo has set up manufacturing facilities in low-risk parts of Asia. SpaceCo's strategy is to develop local suppliers to save on costs to support its regional hubs. While continuing to develop its supply base in emerging markets, it also tries to deepen its relationship with existing suppliers. They create integrated in-region supply chains, which may be referred to as 'clusters'. In essence, SpaceCo focuses on working with existing suppliers by 'migrating' them to a lower-cost country. This helps ensure continuity of supply and to retain the technical know-how for the product lines. For example, one of its European machining suppliers expressed interest in setting up a facility in an emerging market. This initiated a programme through which SpaceCo leveraged its good relations with the government of an emerging nation to develop a cluster of aerospace suppliers in close proximity.

Migrating an existing supplier to a low-cost location is considered a low-risk remote outsourcing option. This helps to mitigate disturbances in a number of ways. For example, it can reduce external supply disturbances such as untimely delivery and mismatched inventory levels. By working with existing suppliers, which already possess technical expertise, it can reduce time to produce, especially during new-product introduction (NPI). It can also mitigate hidden costs of distant production by reducing inventory in the pipeline and thus working capital. These clusters can minimise operational costs and maximise the benefits linked to better coordination and improved communication with suppliers, thus mitigating external control disturbances. SpaceCo also invests time and resources to develop the capabilities of indigenous suppliers further, which has led to significant benefits (according to the Head of Purchasing).

Clusters can lead to competitive advantage if the procurement volume reaches a critical mass, which may be used as leverage to secure the best commercial deals with suppliers. Additionally, SpaceCo encourages its first-tier suppliers in emerging markets to source locally and develop their own supply base. The Programme Manager (Product X) explained:

As a business we are allowing tier 1 suppliers to now fully manage their sub-tier supply chains whereas previously we issued directed

buys. By stopping this practice it allows the tier 1 vendor to source within its own region and leverage their own opportunities.

One of the gearbox suppliers was able to deliver savings in the region of $12 \%$ by pursuing such a local sourcing strategy.

This drive towards an integrated in-region supply chain also enables SpaceCo to exploit opportunities by influencing national and local governments in order to maximise incentives such as grants and concessions, especially in countries and regions promoting the growth of manufacturing locally.

However, clusters may also pose a challenge. For example, geopolitical disturbances such as natural disasters or societal disruptions could impact all members of a regional supply chain at once. Furthermore, disturbances due to cultural disparity need to be mitigated before clusters are set up. Nonetheless, the advantages are manifold. Using clusters, SpaceCo is able to design its supply chain to align with its requirements. The various links in the supply chain benefit, as they can operate almost as one integrated entity, and thus increase efficiency and provide steady reliable business.

\subsection{Reshoring}

Where the benefits of offshoring/outsourcing have not been delivered, SpaceCo has transferred some manufacturing back to its home country. The primary reason for this is to reduce disturbances due to external control factors (Senior Procurement Manager) such as communication problems (Supply Chain Manager) and location-related disturbances such as the risk of IPR infringement, the availability and reliability of infrastructure, and the quality and availability of the labour force (Senior Procurement Manager), as well as disparity in national cultures (Head of Purchasing). Other factors that might lead to reshoring included an increase in automation (Head of Purchasing), complexity of the product (Production Manager and Senior Procurement Manager) and the level of government support such as incentives (grants) and the home government's commitment to long-term capability development (Senior Procurement Manager). To illustrate the last point about political drivers, SpaceCo works closely with the UK government to secure funding to manufacture within the UK, which helps to create local jobs and provides growth for the UK economy. It has taken a leading role in the UK government's 'Sharing in Growth' initiative, which provides around 30 UK suppliers with a tailored, in-depth training and development programme. The aim is to create a competitive group of UK suppliers to help achieve sustainable, competitive performance as the industry continues to grow.

\section{Discussion and conclusions}

This paper investigates how a Europe-based HVM firm rates supply chain disturbances while using one of two supply chain strategies - insource/nearshore, and outsource/offshore. The research empirically examines how HVM managers assess supply chain disturbances. In doing so, it makes some important theoretical contributions. One of the study's underlying 
objectives was to investigate how internally facing managers perceive firm-, network- and location-related supply chain disturbances compared with externally facing managers. We found that there were similarities between the two groups for most of the highly ranked factors. For instance, when the strategy is to outsource/offshore (Asia), both groups ranked unforeseen and random interruptions and difficulty in order processing first and second among the firm-related disturbance factors, ranked communication problems first among the network-related disturbance factors and ranked hidden costs first among the location-related factors.

However, the findings show that managers' perceptions of disturbances can be prejudiced by their functional boundaries. Similarly, Ellis, Henry, and Shockley (2010) noted that risk perceptions, rather than objective measures, are the key drivers of managers' behaviour. In certain cases, the evaluation of supply chain disturbances differ based on whether the decision maker is in an internally or externally facing role. For example, internally facing managers seem to be more prone to the illusion that they are in control. This inherent optimism can cause them to ignore or downplay the possibility of disturbances such as quality defects, which are ranked sixth among the firm-related disturbances by product managers when the strategy is outsource/offshore (Asia) but ranked third by supply chain managers. The results of our study also suggest that internally facing managers' perceptions of disturbances can tend to be myopic. For instance, since the delivery of products is a key function for product managers, they rank the untimely delivery of products second among network-related disturbances while outsourcing or offshoring to Asia. If the managerial perceptions of risk within the same supply chain significantly differ, risk mitigation becomes more difficult (Zsidisin 2003), whereas if internally and externally facing managers have congruent perceptions of supply chain disturbances, then it will be easier to implement effective mitigation strategies.

This paper contributes to the research on sourcing strategies and risk mitigation. We show through our empirical findings that both product and supply chain managers prefer the insource/nearshore outsource strategy, as they feel that the disturbances while outsourcing/offshoring are significantly greater and offset the benefits of low-cost production, a counterintuitive finding. One of the primary reasons for this is that the insource/nearshore outsourcing strategy can have multi-faceted benefits for a firm's production system. For example, shorter delivery lead times make supply chains simpler and more resilient (Hammami, Frein, and Bahli 2017) by reducing the amount of inventory management needed, by mitigating the uncertainties around delivery times, and by avoiding the creation of redundant systems and capacity (Gray et al. 2013; Srai and Ané 2016). Alternatively, reserve lead-time, more inventory and excess capacity, might improve supply chain resilience but at the cost of efficiency (Ivanov and Dolgui 2019).

Other potential advantages include availability of resources like transportation, warehousing, and efficient labour that helps with greater efficiencies. It can also offer benefits in terms of decreasing transaction costs, such as sustainabilityrelated environmental and human rights violations when compared with outsourcing/offshoring (Huq, Stevenson, and Zorzini 2014). Also, certain disturbance factors may spiral out of control when sourcing from distant locations due to the additional transactional cost of interacting with different cultural groups (Tate and Bals 2017; Pawar et al. 2019). For instance, in our case study we found that, due to the difficulties of translating work instructions accurately into the local language, SpaceCo was unable to deliver a critical product to its customer on time and as a result was penalised by the customer. There is also a degree of greater flexibility that insourcing/nearshore outsourcing offers (De Treville and Trigeorgis 2010; Mcivor 2013); for example, having fewer quality defects decreases the burden of hierarchical governance structures (Steven and Britto 2016). Moreover, nearshoring (or reshoring) tends to lessen the impact on production of political instability in foreign countries and mitigates the threat of intellectual property loss (Huq, Pawar, and Rogers 2016; Srai and Ané 2016).

The preference of both product and supply chain managers for insourcing/nearshore outsourcing over outsourcing/offshoring could pertain to economic as well as social advantages. For instance, the UK is one of the major players in global manufacturing. The UK's manufacturing industry contributes 9\% of total European Union sales (Deloitte 2018) and employs approximately 2.5 million people, paying them well above the national average (HVM Catapult 2018). The High Value Manufacturing (HVM) industry (a subset of manufacturing) contributes $£ 275$ billion of Gross Added Value to the UK economy per annum (Institute for Manufacturing 2016). As such, Aerospace - of which SpaceCo is a part - is one of the leading HVM companies in the UK (Innovate UK 2014). Important players in this sector can have a strong economic impact. For example, the European airplane manufacturer Airbus has an annual turnover of £6bn, employs more than 14,000 people and supports an additional 110,000 domestic supply-chain jobs in the UK (Guardian 2019). An active HVM base in the country helps to develop new product markets, thriving innovation, and technologies such as smart factories (Deloitte 2018). HVM benefits the UK because the country has a complementary advantage of world-class science and a technology base that are knowledge driven, and such knowledge is particularly important for building the infrastructure required for HVM. In fact, over the next ten years, advanced manufacturing is expected to speed up innovation, and enable new business models and technologies, thereby boosting UK manufacturing output by $£ 455$ billion, creating 175,000 new jobs while reducing CO2 emissions by 4.5\% (HVM Catapult 2018). The HVM industry also tends to produce spillover benefits across intra-sectorial or cross-industry as firms learn to obtain supplementary or complementary benefits from the innovation and 
developmental activities from their competitors. These activities include borrowing products or ideas, and concepts stimulated by developments related to similar products or technologies (Bednyagin and Gnansounou 2012). Furthermore, the impending 'Brexit' could generate opportunities for the UK's HVM sector by developing the domestic supply chain further, especially its innovation capabilities.

Naturally, firms should opt for the remote outsourcing/offshoring strategy only when the advantages outweigh the drawbacks. In line with this, indeed we find that currently one of the main mitigation strategies for SpaceCo is reshoring. In order to mitigate disturbances, SpaceCo considers the total cost of acquisition, including the hidden costs of distant operations. Labour costs may not be such an important factor in manufacturing, such as HVM, due to existing automation or potential for more large-scale automated manufacturing (Tate et al. 2014). Thus, this calculation method is dynamic; for example, if a manufacturing process previously required a high level of manual input but now can be largely automated, the cost focus shifts to the cost of capital as opposed to labour rates. Perhaps the most interesting mitigation strategy adopted by SpaceCo was that of building clusters in low-cost locations to support its regional hub. The firm develops local supply bases in emerging markets by partnering with its existing suppliers in developed countries, which preserves intellectual property and reduces disturbances.

\subsection{Managerial implications, limitations and future research}

Results from this study inform managerial practice in several important ways. First, HVM firms can benefit from a process that will allow them to rank and compare supply chain disturbances amongst its internally facing and externally facing managers and thus appropriately consider the disturbances without predispositions. For instance, our results show that internally facing managers perceive supply chain disturbances to be less than do externally facing managers when the sourcing strategy is outsourcing/offshoring remotely. This is probably because externally facing managers - who have increased level of ownership of the supply chain - have a more realistic view of the disturbances associated with more dispersed and complex supply chains. Second, using AHP to quantify firm-related, network-related and location-related disturbances, we develop a comprehensive framework which can be utilised (with slight modifications) in other industries. Third, only by understanding how supply chain disturbances are perceived and prioritised by supply chain and productlevel managers can firms take proactive measures for assessing the significance of these disturbance factors and focusing organisational resources to mitigate them.

Even though our study has important managerial implications, it is subject to limitations. For example, as this research is an exploratory single case study, one of the limitations is generalisability. However, it can be argued that the framework (Figure 5) and the mathematical model (Section 4.5) developed from this study relating to categorisation of supply chain disturbance factors is broad and can be utilised by different organisations regardless of what sector they operate in. We also highlight mitigation strategies for dealing with these disturbance factors, which can be applied to different types of risks and uncertainties and thus are generic, at least to an extent. Nonetheless, further studies are required to test these disturbance factors and explore whether they are generalisable to a wider context using other methodological approaches such as a large survey. To add generality to the disturbance factors, future research could investigate if the prioritisation of disturbance factors is replicable at different points of the supply chain (e.g. tier 1 and tier 2 suppliers). Furthermore, our model could serve as a pathway for future researchers for developing a more complex model with complicated characteristics representing realistic nature, which could be stochastic based on probabilistic distributions such as Poisson, exponential and normal. An extension of this research could be to develop a dyadic supply chain risk disturbance framework, incorporating the perspectives of suppliers. Another rich avenue for future investigation would be to focus on the effectiveness of disturbance mitigation strategies in HVM or similar firms.

\section{Disclosure statement}

No potential conflict of interest was reported by the author(s).

\section{ORCID}

Fahian Huq (D) http://orcid.org/0000-0002-2118-617X

Nachiappan Subramanian (D) http://orcid.org/0000-0003-4076-6433

\section{References}

Aqlan, F., and S. S. Lam. 2015. “A Fuzzy-Based Integrated Framework for Supply Chain Risk Assessment.” International Journal of Production Economics 161: 54-63. doi:10.1016/j.ijpe.2014.11.013. 
Baryannis, G., S. Validi, S. Dani, and G. Antoniou. 2019. "Supply Chain Risk Management and Artificial Intelligence: State of the Art and Future Research Directions." International Journal of Production Research 57 (7): $2179-2202$. doi:10.1080/00207543.2018.1530476.

Bednyagin, D., and E. Gnansounou. 2012. "Estimating Spillover Benefits of Large R\&D Projects: Application of Real Options Modelling Approach to the Case of Thermonuclear Fusion R\&D Programme.” Energy Policy 41: 269-279. doi:10.1016/j.enpol.2011.10.046.

Bhatnagar, R., and A. S. Sohal. 2005. "Supply Chain Competitiveness: Measuring the Impact of Location Factors, Uncertainty and Manufacturing Practices." Technovation 25 (5): 443-456.

Bier, T., A. Lange, and C. H. Glock. 2020. "Methods for Mitigating Disruptions in Complex Supply Chain Structures: A Systematic Literature Review." International Journal of Production Research 58 (6): 1835-1856. doi:10.1080/00207543.2019.1687954.

Christopher, M., and M. Holweg. 2011. "Supply Chain 2.0: Managing Supply Chains in the era of Turbulence." International Journal of Physical Distribution \& Logistics Management 41 (1): 63-82. doi:10.1108/09600031111101439.

Christopher, M., and H. Peck. 2004. "Building the Resilient Supply Chain.” International Journal of Logistics Management 15 (2): 1-14.

Deloitte. 2018. Deloitte-Assembling a Strong Future-Industrial Outlook 2018. Accessed 24 March 2020. https://www2.deloitte.com/ content/dam/Deloitte/uk/Documents/manufacturing/deloitte-uk-mfg-industrials-outlook-2018.pdf.

De Treville, S., and L. Trigeorgis. 2010. "It may be Cheaper to Manufacture at Home." Harvard Business Review 88 (10): 84-87.

Dolgui, A., D. Ivanov, and B. Sokolov. 2018. "Ripple Effect in the Supply Chain: An Analysis and Recent Literature." International Journal of Production Research 56 (1-2): 414-430. doi:10.1080/00207543.2017.1387680.

Dong, Q., and O. Cooper. 2016. “An Orders-of-Magnitude AHP Supply Chain Risk Assessment Framework.” International Journal of Production Economics 182: 144-156. doi:10.1016/j.ijpe.2016.08.021.

Ellis, S. C., R. M. Henry, and J. Shockley. 2010. "Buyer Perceptions of Supply Disruption Risk: A Behavioral View and Empirical Assessment." Journal of Operations Management 28 (1): 34-46. doi:10.1016/j.jom.2009.07.002.

Ellram, L. M., W. L. Tate, and C. Billington. 2008. "Offshore Outsourcing of Professional Services: A Transaction Cost Economics Perspective." Journal of Operations Management 26 (2): 148-163. doi:10.1016/j.jom.2007.02.008.

Engineering Employers Federation. 2014. "Backing Britain - A Manufacturing Base for the Future." https://www.eef.org.uk/resourcesand-knowledge/research-and-intelligence/industry-reports/backing-britain-a-manufacturing-base-for-the-future.

Engineeringuk. 2017. "The State of Engineering." http://www.engineeringuk.com/media/1355/enguk-report-2017.pdf.

Euromonitor International. 2017. "China Still Lucrative for Businesses Despite the Rising Wage Rates.” Accessed 10 April 2018. https://blog.euromonitor.com/2017/03/china-still-lucrative-businesses-despite-rising-wage-rates.html.

Foerstl, K., J. F. Kirchoff, and L. Bals. 2016. "Reshoring and Insourcing: Drivers and Future Research Directions." International Journal of Physical Distribution \& Logistics Management 46 (5): 492-515. doi:10.1108/IJPDLM-02-2015-0045.

Forbes. 2017. "Nafta and Brexit will Reshape Logistics Real Estate." Accessed 11 April 2018. https://www.forbes.com/sites/bisnow/2017/ 07/20/nafta-and-brexit-will-reshape-logistics-real-estate/4/\#6d02aad962d7.

Gray, J. V., K. Skowronski, G. Esenduran, and M. Johnny Rungtusanatham. 2013. "The Reshoring Phenomenon: What Supply Chain Academics Ought to Know and Should Do." Journal of Supply Chain Management 49 (2): 27-33. doi:10.1111/jscm.12012.

Guardian. 2013. "Rolls-Royce Missed Several Chances to Fix a380 Engine Problem - Safety Report." Accessed 16 April 2015. http://www.theguardian.com/business/2013/jun/27/rolls-royce-a380-engine-safety-report-qantas.

Guardian. 2018. "Airbus has Delivered a Body Blow to Brexit Britain. It Won't be the Last." Accessed 26 July 2018. https://www.theguardian.com/commentisfree/2018/jun/22/airbus-brexit-britain-commonwealth-plane-wings-north-wales.

Guardian. 2019. “Airbus Brands UK Government Handling of Brexit ‘a Disgrace.” Accessed 16 April 2019. https://www.theguardian. com/business/2019/jan/24/airbus-brands-uk-government-handling-of-brexit-a-disgrace.

Gunasekaran, A., N. Subramanian, and S. Rahman. 2015. "Supply Chain Resilience: Role of Complexities and Strategies." International Journal of Production Research 53 (22): 6809-6819. doi:10.1080/00207543.2015.1093667.

Hammami, R., Y. Frein, and B. Bahli. 2017. "Supply Chain Design to Guarantee Quoted Lead Time and Inventory Replenishment: Model and Insights." International Journal of Production Research 55 (12): 3431-3450. doi:10.1080/00207543.2016.1242799.

Heckmann, I., T. Comes, and S. Nickel. 2015. "A Critical Review on Supply Chain Risk - Definition, Measure and Modeling." Omega 52: 119-132. doi:10.1016/j.omega.2014.10.004.

Ho, W. 2008. "Integrated Analytic Hierarchy Process and Its Applications - a Literature Review." European Journal of Operational Research 186 (1): 211-228.

Ho, W., T. Zheng, H. Yildiz, and S. Talluri. 2015. "Supply Chain Risk Management: A Literature Review." International Journal of Production Research 53 (16): 5031-5069. doi:10.1080/00207543.2015.1030467.

Huq, F., K. Pawar, and H. Rogers. 2016. "Supply Chain Configuration Conundrum: How Does the Pharmaceutical Industry Mitigate Disturbance Factors?" Production Planning \& Control: The Management of Operations 27 (14): 1206.

Huq, F. A., and M. Stevenson. 2018. "Implementing Socially Sustainable Practices in Challenging Institutional Contexts: Building Theory From Seven Developing Country Supplier Cases.” Journal of Business Ethics. doi:10.1007/s10551-018-3951-x.

Huq, F. A., M. Stevenson, and M. Zorzini. 2014. "Social Sustainability in Developing Country Suppliers: An Exploratory Study in the Ready Made Garments Industry of Bangladesh.” International Journal of Operations \& Production Management 34 (5): 610-638.

HVM Catapult. 2018. High Value Manufacturing Catapult Annual Review 2017-2018. Accessed 24 March 2020. https://hvm.catapult.org. uk/wp-content/uploads/2019/01/HVM-Annual-Review-2018-1.pdf. 
Innovate UK. 2014. "High Value Manufacturing Strategy 2012-15." https://www.gov.uk/government/publications/high-valuemanufacturing-strategy-2012-to-2015.

Institute for Manufacturing. 2016. High Value Manufacturing Landscape.

International Business Times. 2014. "Boeing 787: A Complete Timeline of the Dreamliner's Legacy of Failure, After Cracks Discovered in Wings". Accessed 16 April 2015. http://www.ibtimes.com/boeing-787-complete-timeline-dreamliners-legacy-failure-aftercracks-discovered-wings-1560491.

Ivanov, D., and A. Dolgui. 2019. "Low-Certainty-Need (LCN) Supply Chains: A New Perspective in Managing Disruption Risks and Resilience." International Journal of Production Research 57 (15-16): 5119-5136. doi:10.1080/00207543.2018.1521025.

Ivanov, D., A. Dolgui, B. Sokolov, and M. Ivanova. 2017. "Literature Review on Disruption Recovery in the Supply Chain." International Journal of Production Research 55 (20): 6158-6174. doi:10.1080/00207543.2017.1330572.

Kim, Y., Y.-S. Chen, and K. Linderman. 2015. "Supply Network Disruption and Resilience: A Network Structural Perspective.” Journal of Operations Management 33: 43-59.

Kremic, T., O. I. Tukel, and W. O. Rom. 2006. "Outsourcing Decision Support: A Survey of Benefits, Risks, and Decision Factors." Supply Chain Management: An International Journal 11 (6): 467-482. doi:10.1108/13598540610703864.

Lee, H. L., V. Padmanabhan, and S. Whang. 1997. "The Bullwhip Effect in Supply Chains.” Sloan Management Review 38 (3): $93-102$.

Lockamy, A., and K. Mccormack. 2010. “Analysing Risks in Supply Networks to Facilitate Outsourcing Decisions." International Journal of Production Research 48 (2): 593-611. doi:10.1080/00207540903175152.

Maccarthy, B. L., and W. Atthirawong. 2003. "Factors Affecting Location Decisions in International Operations - a Delphi Study." International Journal of Operations \& Production Management 23 (7): 794-818.

Majumdar, A., S. K. Sinha, M. Shaw, and K. Mathiyazhagan. 2020. "Analysing the Vulnerability of Green Clothing Supply Chains in South and Southeast Asia Using Fuzzy Analytic Hierarchy Process." International Journal of Production Research, 1-20. doi:10.1080/00207543.2019.1708988.

Martinez, V., A. Neely, G. Ren, and A. Smart. 2008. High Value Manufacturing: Delivering on the Promise. Advanced Institute of Management Research (AIM).

Mcivor, R. 2013. "Understanding the Manufacturing Location Decision: The Case for the Transaction Cost and Capability Perspectives." Journal of Supply Chain Management 49 (2): 23-26. doi:10.1111/jscm.12010.

Meredith, J. 1998. "Building Operations Management Theory Through Case and Field Research." Journal of Operations Management 16 (4): 441-454. doi:10.1016/s0272-6963(98)00023-0.

Mishra, D., Y. K. Dwivedi, N. P. Rana, and E. Hassini. 2019. "Evolution of Supply Chain Ripple Effect: A Bibliometric and Meta-Analytic View of the Constructs." International Journal of Production Research, 1-19. doi:10.1080/00207543.2019.1668073.

Olivares-Aguila, J., and W. Elmaraghy. 2020. "System Dynamics Modelling for Supply Chain Disruptions." International Journal of Production Research, 1-19. doi:10.1080/00207543.2020.1725171.

Patton, M. Q. 2002. Qualitative Research \& Evaluation Methods. Thousand Oaks, CA: Sage.

Pawar, K. S., F. A. Huq, A. Khraishi, and J. Shah. 2019. "Contextualisation of the Complexity in the Selection of Developing Country Outsourcees by Developed Country Outsourcers.” International Journal of Production Research 57 (13): $4310-4332$. doi:10.1080/00207543.2018.1529444.

Pawar, K., and H. Rogers. 2013. "Contextualising the Holistic Cost of Uncertainty in Outsourcing Manufacturing Supply Chains." Production Planning \& Control: The Management of Operations 24 (7): 607-620.

Ramanathan, R. 2006. "Data Envelopment Analysis for Weight Derivation and Aggregation in the Analytic Hierarchy Process." Computers \& Operations Research 33 (5): 1289-1307.

Ramanathan, U. 2013. "Aligning Supply Chain Collaboration Using Analytic Hierarchy Process.” Omega 41 (2): $431-440$. doi:10.1016/j.omega.2012.03.001.

Rangel, D. A., T. K. D. Oliveira, and M. S. A. Leite. 2015. "Supply Chain Risk Classification: Discussion and Proposal.” International Journal of Production Research 53 (22): 6868-6887. doi:10.1080/00207543.2014.910620.

Rogers, H., K. Pawar, and C. Braziotis. 2012. "Supply Chain Disturbances: Contextualising the Cost of Risk and Uncertainty in Outsourcing." In Decision-Making for Supply Chain Integration, edited by Hing Kai Chan, Fiona Lettice, and Olatunde Amoo Durowoju, 145-164. London: Springer.

Saaty, T. L. 1980. The Analytic Hierarchy Process. New York, NY: McGraw-Hill.

Samvedi, A., V. Jain, and F. T. S. Chan. 2013. "Quantifying Risks in a Supply Chain Through Integration of Fuzzy AHP and Fuzzy Topsis.” International Journal of Production Research 51 (8): 2433-2442. doi:10.1080/00207543.2012.741330.

Spiegler, V. L. M., M. M. Naim, and J. Wikner. 2012. "A Control Engineering Approach to the Assessment of Supply Chain Resilience.” International Journal of Production Research 50 (21): 6162-6187. doi:10.1080/00207543.2012.710764.

Srai, J. S., and C. Ané. 2016. "Institutional and Strategic Operations Perspectives on Manufacturing Reshoring." International Journal of Production Research 54 (23): 7193-7211. doi:10.1080/00207543.2016.1193247.

Steven, A., and R. Britto. 2016. "Emerging Market Presence, Inventory, and Product Recall Linkages." Journal of Operations Management 46: 55.

Subramanian, N., and R. Ramanathan. 2012. "A Review of Applications of Analytic Hierarchy Process in Operations Management." International Journal of Production Economics 138 (2): 215-241. 
Subramoniam, R., D. Huisingh, R. B. Chinnam, and S. Subramoniam. 2013. "Remanufacturing Decision-Making Framework (Rdmf): Research Validation Using the Analytical Hierarchical Process." Journal of Cleaner Production 40: $212-220$. doi:10.1016/j.jclepro.2011.09.004.

Tate, W. L. 2014. "Offshoring and Reshoring: U.S. Insights and Research Challenges.” Journal of Purchasing and Supply Management 20 (1): 66-68. doi:10.1016/j.pursup.2014.01.007.

Tate, W. L., and L. Bals. 2017. "Outsourcing/Offshoring Insights: Going Beyond Reshoring to Rightshoring." International Journal of Physical Distribution \& Logistics Management 47 (2/3): 106-113. doi:10.1108/IJPDLM-11-2016-0314.

Tate, W. L., L. M. Ellram, L. Bals, and E. Hartmann. 2009. "Offshore Outsourcing of Services: An Evolutionary Perspective." International Journal of Production Economics 120 (2): 512-524. doi:10.1016/j.ijpe.2009.04.005.

Tate, W. L., L. M. Ellram, T. Schoenherr, and K. J. Petersen. 2014. "Global Competitive Conditions Driving the Manufacturing Location Decision.” Business Horizons 57 (3): 381-390. doi:10.1016/j.bushor.2013.12.010.

Telegraph, T. 2018. "Former Rolls-Royce Engineer 'Arrested Under Official Secrets Act' Amid Fears China Tried to Obtain f-35 Fighter Jet Details." https://www.telegraph.co.uk/news/2018/06/14/former-rolls-royce-engineer-arrested-officials-secrets-act-amid/.

Truong Quang, H., and Y. Hara. 2018. "Risks and Performance in Supply Chain: The Push Effect." International Journal of Production Research 56 (4): 1369-1388. doi:10.1080/00207543.2017.1363429.

U.S. Department of Commerce. 2016. "Labor Costs.” Accessed 2 June 2017. http://acetool.commerce.gov/labor-costs.

United States Department of Commerce. 2017. "Labor Costs.” Accessed 10 April 2018. https://acetool.commerce.gov/labor-costs.

Wagner, S. M., and N. Neshat. 2012. "A Comparison of Supply Chain Vulnerability Indices for Different Categories of Firms." International Journal of Production Research 50 (11): 2877-2891. doi:10.1080/00207543.2011.561540.

Wang, X., and Y. Zhang. 2014. "What's High-Value Engineering and Its Influencing Factors in International Network Operations?" In International Operations Networks, edited by J. Johansen, S. Farooq, and Y. Cheng, 133-148. London: Springer.

Wu, D. D., C. Luo, and D. L. Olson. 2014. "Efficiency Evaluation for Supply Chains Using Maximin Decision Support." IEEE Transactions on Systems, Man, and Cybernetics: Systems 44 (8): 1088-1097.

Xu, S., X. Zhang, L. Feng, and W. Yang. 2020. "Disruption Risks in Supply Chain Management: A Literature Review Based on Bibliometric Analysis.” International Journal of Production Research, 1-19. doi:10.1080/00207543.2020.1717011.

Zhang, Y., and M. Gregory. 2011. "Managing Global Network Operations Along the Engineering Value Chain." International Journal of Operations \& Production Management 31 (7): 736-764. doi:10.1108/01443571111144832.

Zhang, Y., M. Gregory, and A. Neely. 2016. "Global Engineering Services: Shedding Light on Network Capabilities.” Journal of Operations Management 42-43: 80-94. doi:10.1016/j.jom.2016.03.006.

Zhang, B., D. Wu, L. Liang, and D. L. Olson. 2015. "Supply Chain Loss Averse Newsboy Model with Capital Constraint." IEEE Transactions on Systems, Man, and Cybernetics: Systems 46 (5): 646-658.

Zsidisin, G. A. 2003. "Managerial Perceptions of Supply Risk.” Journal of Supply Chain Management 39 (1): 14-26. 